\begin{tabular}{|l|l|} 
Academic & $\begin{array}{l}\text { Institut Agama Islam Negeri (IAIN) Curup, Indonesia } \\
\text { Journal of } \\
\text { Islamic Studies }\end{array}$ \\
& ISSN 2580-3174, (p); 2580-3190 (e) \\
& volume 6, number 1, 2021 | page: 117-134 \\
DOI: http://doi.org/10.29240/ajis.v6i1.2840
\end{tabular}

\title{
The Implementation of the Character Education Strengthening (PPK) Movement in the Junior High Schools (SMPN) Kerinci Regency
}

\author{
Ahmad Jamin'1, Deri Wanto², Sapriadi ${ }^{3}$ \\ 1,3IAIN Kerinci, ${ }^{2}$ IAIN Curup, Indoneisa \\ ahmadjamin81@gmail.com, deriwanto@iaincurup.ac.id, sapriadi0907@gmail.com
}

\begin{abstract}
The PPK movement launched by the government is a response to the phenomenon of moral decadence/character crisis that occurs in almost all levels and sectors of life, including in the world of education. The PPK movement aims to instill and strengthen the values of the nation's character in the education unit. This study aims to describe the implementation of the PPK movement in the SMPN Kerinci regency by using qualitative research design and case study approach, namely in SMPN 13, SMPN 15, and SMPN 48. Data were collected through observation, unstructured interviews, and documentation. The data collected was then analyzed with Miles and Huberman techniques with data reduction, display, and conclusion drawing stages. The implementation of PPK has been running quite well. It positively impacts strengthening students' character characterized by increased discipline, honesty, responsibility, creativity, social care, and so on. However, the implementation of the PPK movement still has some constraints as teachers do not understand the essence and urgency of the PKK movement comprehensively and completely. In addition to other factors such as inadequate learning facilities and resources and still lack of support from stakeholders and the community.
\end{abstract}

Keywords: Character Education, PPK Implementation, Junior High School

\section{Introduction}

Character Education Strengthening (After this referred to as PPK) Movement is a continuation and revitalization of the national movement of character education based on the National Action Plan (RAN) of National Character Education starting in 2010 following the spirit of Law No. 20 of 2003 on The National Education System.

The PPK movement is becoming increasingly urgently prioritized as a response and anticipation to the moral decadence/character crisis that occurs in almost all levels and sectors of life. In the order of state life, the character crisis is indicated by the rise of intolerant action and violence that threatens the diversity and integrity of the Republic of 
Indonesia and the increasing rate of corruption in all sectors. Meanwhile, in society's social life order, there are often horizontal conflicts, environmental destruction, and others. Then in the world of education, there is a fight between students, teacher violence against students, bullying between participants, and even criminal acts troubling the community.

The phenomenon of character crisis shows that there are weaknesses/mistakes in the education system that runs so far because it is felt that it has not managed to build Indonesian people with character. For so long, the education system is more focused on thinking or developing aspects of knowledge (cognitive oriented) and ignores efforts to develop attitudes, morals, and character. The condition is affirmed by Muhadjir Effendy, who states that our education actually misses or ignores some crucial dimensions in education, namely sports (kinesthetic), taste (art), and ethics (spiritual). ${ }^{1}$ Furthermore, it indicates that education has not optimally played its role in character building because many graduates of educational institutions in Indonesia, including scholars who are intelligent and proficient in answering exam questions, have intelligent brains, but they do not have a strong mentality, even they tend to be immoral. ${ }^{2}$

To address the issue, the Government issued Presidential Regulation (Perpres) No. 87 of 2017 on Strengthening Character Education. It is described by Permendikbud No. 20 of 2018 on PPK article 1 paragraph (1) explained that PPK is an educational movement under the responsibility of the education unit to strengthen the character of learners through harmonization of ethics, art, thinking, and sports, and society as part of the National Movement of Mental Revolution (GNRM). ${ }^{3}$ Therefore, the 2013 curriculum, as a reference for the learning process in the education unit, has directed learning by integrating PPK into it. The integration is not an additional program or insertion but a way of educating and learning for all educational actors in the education unit.

The PPK movement is directed to developing and strengthening the noble values of Pancasila, which are reflected in the 5 (five) main

1 Muhadjir Effendy, "No TitleArahan Menteri Pendidikan Dan Kebudayaan Muhadjir Effendy Dalam Pelatihan Pengembangan Kapasitas Untuk Penguatan Pendidikan Karakter" (2016).

2 Heri Gunawan, Pendidikan Karakter Konsep Dan Implementasi, Cet. Ke-1 (Bandung: Alfabeta, 2012), 29.

${ }^{3}$ Peraturan Presiden, “Penguatan Pendidikan Karakter," Pub. L. No. No. 87 Pasal 1 Ayat 1 (2017). 
values, namely religiosity, nationalism, independence, mutual cooperation, and integrity integrated into the curriculum. The five main values are further described as the value of good characters education, namely religious character, honest, tolerant, disciplined, hard work, creative, independent, democratic, curiosity, national spirit, love of homeland, appreciate achievements, communicative, peace-loving, fond of reading, environmental care, social care, and responsibility. ${ }^{4}$

The development and strengthening of noble character values are carried out by integrating character values in all subjects and strengthened through habituation activities and civilizing so that the nation's character education can really change the behavior of the way of thinking and how to act throughout the Indonesian nation for the better and have integrity. PPK implementation is carried out by optimizing three education centers with a class-based approach, school culture, and community. ${ }^{5}$ Furthermore, the PPK program is integrated into the whole education system, school culture, and cooperation with the community. PPK program is expected to foster the spirit of learning and make students happy in school as a friendly home to grow and develop.

Therefore, any events or activities in the school can be integrated into the character education policy. Thus, character education is a joint effort of all components of the school to create a positive culture in students' personalities.

Follow up on the PPK movement launched by the government, some junior high schools (SMPN) in Kerinci regency have implemented the PPK movement in reference to the rules and guidelines that have been set as happened in SMPN 13, SMPN 15, and SMPN 48. The implementation of PPK has a positive impact on strengthening the character of students.

Based on the above problems, this article seeks to describe the implementation of the PPK movement in the SMPN in Kerinci Regency, case studies in 3 junior high schools in Kerinci regency, namely SMPNN 13, SMPNN 15, and SMPNN 48 Kerinci. This research is expected to add knowledge and broaden insights about character education, especially in implementing PPK policy in the school environment both at the elementary and secondary school levels. In addition, the results of this study are expected to provide input for principals, teachers, and

4 Permendikbud, "Penguatan Pendidikan Karakter Pada Satuan Pendidikan Formal," Pub. L. No. No. 20 Pasal 2 (2018).

5 Permendikbud, Pasal 5. 
stakeholders in designing and implementing the PPK movement more effectively and efficiently.

This study used the qualitative design that produces descriptive data, either written or oral, 6 by finding and describing information about the implementation of the PPK movement in SMPN Kerinci. Specifically, it used case study approaches in SMPNN 13, SMPNN 15, and SMPNN 48.7 Researchers observed, explored, and studied in depth the phenomena of the plan and the form and impact of PPK implementation on strengthening the character of learners. The informants consisted of principals, teachers, students selected using purposive sampling techniques. $^{8}$ Data was gathered through observations, unstructured interviews, and documentation, with observation sheet instruments, interview guidelines, and documentation guidelines. The data collected was then analyzed with Miles and Huberman techniques with data reduction, display, and conclusion drawing stages. ${ }^{9}$

\section{Results and Discussion}

The implementation of PPK in SMPN Kerinci is divided into two stages, namely the pre-implementation stage and the implementation stage:

\section{Pre-Implementation Stage}

In the pre-implementation stage, schools, as PPK organizers, prepare everything related to implementing PPK, starting from determining the school's vision, setting school branding, program preparation, program socialization, and preparation of facilities, infrastructure, and supporting equipment. The results of interviews and observations in the field about the pre-implementation of PPK can be explained as follows: 2014), 4.

${ }^{6}$ Lexy J Moleong, Metode Penelitian Kualitatif (Bandung: Remaja Rosdakarya,

${ }^{7}$ John W Creswell, Qualitatif Inquiry and Designe Research Choosing among Five Approaches (London: Sage Publications, 2007), 73.

8 Moleong, Metode Penelitian Kualitatif, 224.

${ }^{9}$ Miles and Huberman, Analisis Data Kualitatif, Buku Sumber Tentang MetodeMetode Baru (Jakarta: Universitas Indonesia Press, 2007), 223. 


\section{a. Determination of School Vision}

Implementing PPK begins when the formulation of the vision and mission of the school in which it accommodates and reflects the central values of PPK. In formulating the vision and mission of the school, SMPN 13, SMPN 15, and SMPN 48 have integrated the values and spirit of the PPK movement, in which the formulation of the vision and mission of the school has been reflected in the strengthening of noble character values. For example, improving faith and piety, discipline, independence, responsibility, noble ethics and politeness, and others.

The head of SMPN 13 stated that the vision and mission of the school is "the realization of educational institution which is harmonious, godly, intelligent and skilled. Then the mission is basically to increase the passion for religion, culture, and nation, improve the learning achievements of learners and increase the sense of humanity".10 The head of SMPN 15 Kerinci explained: "the vision and mission of our school to be a solid, polite, optimistic, loyal, faith and piety and discipline."11 Similarly, the statement from the head of SMPN 48 Kerinci stated that the vision of the school is: "to shape our students into human beings with moral and intellectual, polite, qualified amid a society in the future, forming independent, disciplined and responsible human beings."12

\section{b. Determination of School Branding}

In addition to establishing the vision and mission of the school, the implementation of PPK can also be reflected in the school's existence, establishing the school branding as part of efforts to foster students' character.

According to the results of research on school branding (typical of the school), it was concluded that junior high schools in Kerinci regency, especially in the three junior high schools, have implemented PPK in their respective schools by establishing the characteristics or excellence of the school (branding school) that meets the needs and culture of the school or adapts the culture of the surrounding area. Among the branding school (characteristic/excellence of the school), it is clean, comfortable (environment), then polite, intelligent, responsible (Learners). From some form of characteristic or excellence of the school, this has shown the existence of a form of PPK implementation in their respective schools.

\footnotetext{
${ }^{10}$ Reprianis, "Interview Principal of SMPN 13 Kerinci" (2020), n. 20 June.

11 Damrus, "Interview Principal of SMPN 15 Kerinci" (2020), n. 16 June.

12 Safarial, "Interview Principal of SMPN 48 Kerinci" (2020), n. 15 June.
} 
The head of SMPN13 Kerinci stated, "The branding of our school is to make the school clean, comfortable, and cultured." 13 Furthermore, the head of SMPN 15 Kerinci explained, "Our school branding is to form students who are polite in their attitude, polite in doing and environmentally minded." 14 Meanwhile, according to the head of SMPN 48 Kerinci, the school's uniqueness is to "form smart and responsible students both in school and in the community later."15

c. Preparation of School Work Program

The implementation of the PPK program in schools should also be reflected in the School Work Plan (RKS) or School Budget for Work Plan (RKAS). In RKS/RKAS, it is explained about the vision, mission, school objectives, school branding, medium-term goals and short-term goals, and usage plan of the school budget.

The strategic program designed by this school must demonstrate efforts to achieve quality educational objectives both in terms of students' knowledge, attitude, and skills. Therefore, in RKS /RKAS must be drawn a work plan that accommodates the PPK program.

Related to the composition of the School Work Plan (RKS), the head of SMPNN 13 Kerinci stated, "we have accommodated the values of PPK in RKS."16 The same statement was also delivered by the head of SMPN 15 Kerinci, who stated, "Alhamdulillah (praise be to God) we have included one of them, character-building activities that we put in rohis (spiritual) and scout activities,"17 similarly, the head of SMPN 48 Kerinci stated, "God willing, it has been done."18

Based on the results of interviews with the principals, it is known that the schools as research objects have compiled RKS/RKAS in which they have accommodated the implementation of the PPK program.

\footnotetext{
${ }^{13}$ Reprianis, "Interview Principal of SMPN 13 Kerinci," n. 18 June.

${ }^{14}$ Damrus, "Interview Principal of SMPN 15 Kerinci," n. 16 June.

${ }^{15}$ Safarial, "Interview Principal of SMPN 48 Kerinci," n. 15 June.

16 Damrus, "Interview Principal of SMPN 15 Kerinci," n. 16 June.

17 Damrus, n. 16.

${ }^{18}$ Safarial, "Interview Principal of SMPN 48 Kerinci," n. 15 June.
} 


\section{d. Program Socialization}

In order to inform the implementation plan of the PPK movement, the school has conducted socialization to all parties, especially to school personnel, educators, educational personnel, school committees, other stakeholders, and even to the community.

In socializing the PPK program, SMPN 13 Kerinci conducts socialization by carrying out technical guidance activities to teachers/educators, educational personnel, and school committees with the aim that they understand the policies of PPK both class-based, school culture, and community-based. Meanwhile, at SMPN 15 Kerinci, in socializing the PPK program, it conducts meetings either through meetings with teacher assemblies, student council meetings, or school committee meetings. Through the meeting, all school programs related to the implementation of PPK are delivered. Likewise, at SMPN 48, through meetings and extra-curricular activities.

The principal of SMPN 13 stated; "for the socialization of PPK movement, implemented through technical guidance, technical guidance of the school by bringing resource persons from the education office so that we understand character education both class-based, school culture, family and community."19 Meanwhile, the head of SMPN 15 Kerinci explained; "the way we socialize the PPK program through teacher assembly meetings, then followed up with student council meetings that are not separated also by coordination with committee meetings or parents of students. Moreover, alhamdulillah (thank God) parents are very supportive". ${ }^{20}$ In contrast to what was conveyed by the head of SMPN 48 Kerinci, who stated, "We are from SMPN 48 Kerinci with all stakeholders, and our students hold extra activities such as yasinan (read prayers and Surah Yasin together), then scouting, then there is a kind of religious activity other than yasinan (read prayers and Surah Yasin together) that is teaching children to pray outside school hours and also sports".21

\footnotetext{
${ }^{19}$ Reprianis, "Interview Principal of SMPN 13 Kerinci," n. 18 June.

20 Damrus, "Interview Principal of SMPN 15 Kerinci," n. 16 June.

${ }^{21}$ Safarial, "Interview Principal of SMPN 48 Kerinci," n. 15 June.
} 
e. Preparation of Facilities and Infrastructure

To support the implementation of PPK to be carried out to the maximum, the school provides the necessary facilities and infrastructure for implementing the PPK movement. The national standards of education (SNP) that the government is obliged to do still need to be improved. While improving the quality of school facilities and infrastructure can be done by involving community participation in accordance with the needs and context of the school needs to be developed. The facilities and infrastructure required in PPK development include classrooms, library, laboratory, religious activity rooms, skill rooms, art rooms, sports facilities, adequate budgets, and other educational equipment.

The head of SMPN 13 Kerinci stated, "for the achievement of PPK objectives, of course, the school prepares the facilities needed by the stakeholders in SMPN 13.22 Thus the explanation from the head of SMPN 15 Kerinci also stated, "Preparing rohis (spiritual) room, student council program, rohis (spiritual) program and supported with the relevant budget. ${ }^{23}$ Meanwhile, a statement from the head of SMPN 48 Kerinci explained," to support the PPK movement; we prepare all equipment related to relevant activities. For example, yasinan (read prayers and Surah Yasin together) means that the school prepares the Surah Yasin, then scouts; the school prepares the scouting activities. ${ }^{24}$

The statements delivered by the principal were reinforced by remarks from several teachers, who all stated that the school always facilitates PPK activities in their respective schools. Among the explanations was delivered by one of the teachers at SMPN 15 Kerinci, who stated, "Yes, very facilitated. So I see like the school approves rohis (spiritual) activities, there are mutual cooperation activities, it is all a form of the school supports that PPK goes well in school. ${ }^{25}$ Then the same explanation was also conveyed by one of the teachers of SMPN 48 Kerinci, who revealed: "Yes... the school always facilitates implementing PPK, such as applying religious activities, group learning, and many other activities that the school facilitates according to existing abilities. ${ }^{26}$

\footnotetext{
22 Reprianis, "Interview Principal of SMPN 13 Kerinci," n. 18 June.

${ }^{23}$ Damrus, "Interview Principal of SMPN 15 Kerinci," n. 16 June.

${ }^{24}$ Safarial, "Interview Principal of SMPN 48 Kerinci," n. 15 June.

25 Putri Permata Sari, "Interview Teacher of SMPN 15 Kerinci” (2020), n. 4
} August.

${ }^{26}$ Mesra Melta, "Interview Teacher of SMPN 48 Kerinci” (2020), n. 3 August. 


\section{Implementation Stage}

The guidelines for the implementation of PPK mentioned that PPK implementation is carried out with three main approaches: class-based, school culture-based, and community-based. ${ }^{27}$ These three approaches are interconnected and are a whole entity. This approach can help the education unit in designing and implementing PPK programs and activities. Referring to the guidelines, the implementation of the movement in SMPN Kerinci is implemented through:

a. Implementation of PPK based on the class

Class-based PPK implementation is carried out through integration in curriculum, selection of learning methods, authentic assessment, and mentoring activities through counseling guidance.

1) Integration of PPK in Curriculum.

As it is understood that character education is integrated into all subjects in the school. Thus, in the RPP (lesson plan) preparation, subject teachers have tried to integrate the values of PPK following the curriculum that has been set.

One of the teachers at SMPN 13 Kerinci stated, "I have played an active role in implementing this PPK through subjects, by integrating PPK values in learning, including in its planning RPP (lesson plan) has also been applied PPK values, and its implementation has also been applied well, has been verified, combined with the values of PPK, religiosity, nationalism, independence, mutual cooperation, integrity has been integrated into the RPP compiled. ${ }^{28}$ Then at SMPN 15 Kerinci, it was conveyed by one of the teachers that " in RPP (lesson plan) we have integrated the values of PPK." Next, other educators, including data obtained from informants from SMPN 48 Kerinci, all stated that they had compiled RPP (lesson plan) in which had integrated the central values of PPK.

${ }^{27}$ Hendarman and Dkk, Konsep Dan Pedoman Penguatan Pendidikan Karakter, Cet. Ke-2 (Jakarta: Kemendikbud, 2018), 27.

${ }^{28}$ Ade Candra, "Interview Teacher of SMPN 13 Kerinci" (2020), n. 16 June. 
2) PPK through the choice and use of learning methods.

In terms of choosing a learning method to develop the central values of PPK in learning, the researchers obtained various explanations from the teachers interviewed. For example, one of the resource persons from SMPN 13 Kerinci said, "I use more scientific learning methods. ${ }^{29}$ According to another teacher, "in my opinion, a suitable method is a cooperative learning method, then the discussion method. ${ }^{30}$ Meanwhile, data obtained at SMPN 15 Kerinci shows that one of the teachers mentioned, "Yes... lectures, discussions, questions, and answers. ${ }^{31}$ Another data that the researchers obtained mentioned "Lecturing method, method of being role model for example: may not be like that, it should not be, this is lecturing method, ${ }^{32}$ so it is data from other informants. Furthermore, the interview data obtained at SMPN 48 Kerinci stated, "the first to give tasks in groups and later will be presented in the form of discussions and also in the form of portfolio reports, then also conduct extra-curricular activities." 33

From the results of the RPP (lesson plan) study, an explanation of the methods used has shown an effort to involve students in learning. It is certainly intended for the learning process to be integrated with efforts to instill the core values of PPK. However, in the results of indirect observation of learning activities in the classroom, there is a discrepancy between the methods specified in the RPP (lesson plan) and the practice in the classroom. For example, in RPP (lesson plan), it is written that the method used is scientific, but in the learning process in the class, the method used mostly lecturing and Questions and Answers methods. Whereas in RPP (lesson plan) preparation, the method used has been designed a learning scenario that is integrated into strengthening character education.

Based on this information, teachers are expected to determine and apply the proper methods in the planning and learning process so they can indirectly instill good character values to students and provide useful knowledge and skills for students.

3) Carry out authentic assessments

${ }^{29}$ Rahma Kumara D, "Interview Teacher of SMPN 13 Kerinci” (20202), n. 6 August.

${ }^{30}$ Nurjanah, "Interview Teacher of SMPN 13 Kerinci” (2020), n. 23 July.

31 Zulkifli, "Interview Teacher of SMPN 15 Kerinci" (2020), n. 21 July.

32 Niswarti, "Interview Teacher of SMPN 15 Kerinci" (2020), n. 14 July.

${ }^{33}$ Heris Deka Putra, "Interview Teacher of SMPN 48 Kerinci” (2020), n. 20 July. 
The next step in implementing PPK through class-based activities is to carry out authentic assessments in the learning process. After being observed RPP (lesson plan) documents from several teachers, data was obtained that almost all RPP (lesson plan) compiled already listed assessment techniques, assessment attitude, knowledge, and skills. Even in attitude assessment techniques, there are already those that include instruments of attitude assessment in the form of journals, selfassessment, and paired assessment. Likewise, knowledge assessment in RPP (lesson plan) has already been listed about written tests in the form of multiple-choice or essays, assignments, and homework. The assessment of skills has also been listed in several assessment formats, such as portfolio assessment format, project assessment format, and so on.

The explanation from the teacher at SMPN 13 Kerinci mentioned, "we do authentic research by directly observing students' attitude and character. For his religious character through prayer activities at the beginning and at the end of the learning hours. Then if the value of nationalism is singing the song, Indonesia Raya, together and the flag ceremony, then the value of PPK independence I give guidance and encouragement for students to do activities independently. Then if the value of mutual cooperation teachers, I, and all students are helping students who have difficulty in learning. For its integrity value, I apply the habit of coming early to welcome students so that it can affect students. Moreover, apply honesty achievements with students. ${ }^{34}$ The teacher of SMPN 15 stated, " implementing prayers at the beginning of the lesson, at the end of the lesson is also closed with prayers, prioritizing discipline, honesty, responsibility for the task given to students." 35 While the third informant said, "especially we have to look at the material that corresponds to the learning and by having to adjust between the subject matter and the strengthening of this character education." ${ }^{36}$ Likewise, the teacher at SMPN 48 Kerinci explained, "there I enter honesty, then pray, then discipline and responsibility and familiarize students to say greetings every time they enter the classroom, then express their

${ }^{34}$ Candra, "Interview Teacher of SMPN 13 Kerinci," n. 14 July.

35 Nurjanah, "Interview Teacher of SMPN 13 Kerinci," n. 23 July.

${ }^{36}$ Rismawati, Teacher of SMPN 13 Kerinci, Interview, (Sanggaran Agung, 30 July 2020). 
opinions politely, also continue to appreciate the opinions of other friends."37

4) The Implementation of PPK through guidance and counseling services

Besides being integrated into the subjects (curriculum), the implementation of PPK in SMPN in Kerinci Regency is also integrated with student mentoring activities on guidance and counseling. In supporting the implementation of PPK in SMPN in Kerinci District by activating counseling services to help students with problems and assisting students in developing various potentials, including the development of learning / academic aspects, career, personal, and social. Counseling guidance activities are conducted collaboratively with subject teachers, educational personnel, parents, and other stakeholders.

b. Implementation of PPK Based on School Culture

In addition to character education based on class, the Concept book and PPK Guidelines also explain character education based on school culture. According to Hendarman in the book explained, "Character education based on school culture is an activity to create a climate and school environment that supports PPK praxis overcome classrooms and involve the entire system, structure, and educational actors in schools." 38

Implementation of PPK based on school culture, implemented through:

\section{1) Habituation}

One of the teachers of SMPN 13 Kerinci revealed, "the usual thing to do or habituation is like greetings with the teacher after the flag ceremony, then the school also performs dhuha prayers, yasinan (read prayers and Surah Yasin together), then the school performs the celebration of religious holidays. Also, the school increases students' reading interest, namely through compulsory reading, in every class it exists. Then also applied the school picket system, it was not only teachers but also students. Then there is the collection of donations for students who were affected by the disaster. "39 Then, one of the teachers at SMPN 15 Kerinci argued, "in school, every time they arrive at school students shake hands with the teacher when they meet the teacher directly shake

37 Rismawati, "Interview Teacher of SMPN 13 Kerinci" (2020), n. 30; Putra, "Interview Teacher of SMPN 48 Kerinci," n. 20 July.

${ }^{38}$ Hendarman and Dkk, Konsep Dan Pedoman Penguatan Pendidikan Karakter, 35.

${ }^{39}$ Candra, "Interview Teacher of SMPN 13 Kerinci," n. 16 June. 
hands or say greetings. Then in class, they pray every morning in the morning roll call, except Monday; it is a flag ceremony, and tadarus (reading Al-Qur'an) before entering the class".40 Similarly, another teacher revealed, "The habits of students in this school usually say greetings when meeting with the teacher and his friend, and usually on Tuesday morning until Thursday we conduct tadarus (reading Al-Qur'an) before the learning hours begin." 41 Furthermore, the teachers of SMPN 48 Kerinci said, "The habituations carried out in our school such as children greeting and shaking hands every time they meet the teacher or principal, carry out ant operations every Friday morning. Always start the lesson by praying as well as at the end of the lesson". ${ }^{42}$

From the picture above, it is understood that in the three Junior high schools in Kerinci Regency, they have done good habituation to foster students' character both in religion, nationalist, mutual cooperation, independence, and integrity. Habituations are done, such as students pray before and at the end of the lesson, get used to saying greetings every time they meet the headteacher, teachers, shake hands and kiss the teacher's hand every time they meet, speak politely, do the teacher's orders and always get used to throwing garbage in place and so on.

It is in line with Hendarman's opinion that "Strengthening character education based on school culture focuses on habituation and the formation of a culture that represents the main values of PPK which are the priority of the education unit. This habituation is integrated into the school's overall activities, which is reflected in the conducive atmosphere and environment". ${ }^{43}$ Thus, the education unit can develop PPK based on school culture by strengthening the tradition (habituation) already owned by the school. In addition to develop something which has already good, the education unit still needs to evaluate and reflect itself, whether the traditions inherited in the education unit are still relevant to the needs and present conditions or need to be revised in order to answer the growing challenges, and in line with the efforts to strengthen the character in the education unit.

2) The development of Co-Curricular Activities. 35.

${ }^{40}$ Niswarti, "Interview Teacher of SMPN 15 Kerinci," n. 14 July.

${ }^{41}$ Zulkifli, "Interview Teacher of SMPN 15 Kerinci," n. 21 July.

42 Melta, "Interview Teacher of SMPN 48 Kerinci," n. 3 August.

${ }^{43}$ Hendarman and Dkk, Konsep Dan Pedoman Penguatan Pendidikan Karakter, 
The next step in implementing PPK based on school culture is through the development of co-curricular activities. According to the head of SMPNN 13 Kerinci, "There are many activities that we do in schools, such as cleaning the environment and making wall magazines." 44 Then one of the teachers of SMPN 13 Kerinci added, "as far as I know there are four activities, the first is religious activities for example: commemorating religious holidays, then every Friday is reading Surah Yasin together or interspersed with dhuha prayers, then scouting activities, art activities, sports activities." 45 Furthermore, another teacher mentioned, "The first co-curricular activities conducted in school was congregational prayers, then field trips and also then there was an art practice." 46

Meanwhile, the head of SMPN 15 Kerinci said, the co-curricular activities in his school; "The first is dhuha prayer, dhuha prayer and zuhur prayer in the congregation from Monday to Thursday. Then, memorize short surah of Al-Qur'an, memorization of prayers, memorization of asma'ul husna and kultum (seven minutes religious speech) for students". ${ }^{77}$ One of his teachers explained, "As I know, the religious activities are; reading Surah Yasin together every Friday morning, also perform dhuha prayers, commemorating the religious holidays. The other activities are art activities, scouting activities and sports activities".48 Concerning the co-curricular activities held at SMPN 15 Kerinci, Another teacher revealed, "there are rohis (spiritual activities), scouts, in every morning for the public there is religious speech, lectures, and in Friday morning there is reading Surah Yasin together. Finished reading Surah Yasin, there are actually divided into two activities; there are some students who read Surah Yasin and two classrooms to pray dhuha and guided by teachers, there are two teachers or three teachers guide students who pray dhuha." 49

Furthermore, the head of SMPN 48 Kerinci explained, "cocurricular activities conducted at SMPN 48 Kerinci such as yasinan (reading Surah Yasin together), sports, read short verses of Al-Qur'an and there are clean Friday activities. It means that we will put the child into this school before special lesson hours, on Friday to be carried out ant

\footnotetext{
${ }^{44}$ Reprianis, "Interview Principal of SMPN 13 Kerinci," n. 18 June.

${ }^{45}$ Nurjanah, "Interview Teacher of SMPN 13 Kerinci," n. 23 July.

${ }^{46}$ D, "Interview Teacher of SMPN 13 Kerinci," n. 6 August.

47 Damrus, "Interview Principal of SMPN 15 Kerinci," n. 16 June.

48 Idialisna, "Interview Teacher of SMPN 15 Kerinci" (2020), n. 14 July.

${ }^{49}$ Niswarti, "Interview Teacher of SMPN 15 Kerinci," n. 14 July.
} 
operation to clean the environment, then wash his/her new hands after that he/she learns in the classroom." 50 Furthermore, according to the informant from the teacher explaining about some co-curricular activities carried out at SMPN 48 Kerinci. The teacher added, "Our co-curricular activities include library visits or literacy, group work, learning prayer practices for religious teachers, Al-Qur'an reading practices for Iqra teachers'.51 In contrast to the next informant who said that the cocurricular activities carried out at SMPNN 48 Kerinci are "There are scouts, then Zuhur prayers in congregation, PMR (Youth Red Cross), also sometimes there is self-defense activities. ${ }^{52}$

3) Implementation of PPK through extra-curricular.

Strengthening the main values of PPK is very possible to be implemented through extra-curricular activities aimed at developing the personality and talents of learners in line with their interests and abilities. There are two types of extra-curricular activities, namely the obligation one (education scouting) and optional extra-curricular activities (in accordance with the extra-curricular activities developed by each educational unit). ${ }^{53}$

There are several types of extra-curricular activities conducted in order to develop the good character of students. At SMPN 13 Kerinci, the researchers obtained the explanation from the teacher who explained, "Extra-curricular such as scouting is done; also there are PMR (Youth Red Cross), PASKIBRAKA (National Flag Hoisting Troops), cultural arts, religious activities, sports activities, language activities, journalism and also scientific work of adolescents." ${ }^{4}$ At SMPN 15 Kerinci, the teacher informed, "Extra-curricular activities are developing students' potential, talents, and interests through, for example, student council activities, scouts, Rohis (spiritual) activities, performing arts, and so on." 55 At SMPN 48 Kerinci, the principal conveyed the information about extra-curricular activities; "Our extra-curricular activities are certainly included, they are dance activities, scouting activities. They are included in extra-curricular activities. Then there are PMR (Youth Red Cross) activities". 56 Then, one

${ }^{50}$ Safarial, "Interview Principal of SMPN 48 Kerinci," n. 15 June.

${ }^{51}$ Melta, "Interview Teacher of SMPN 48 Kerinci," n. 3 August.

52 Irmawati, "Interview Teacher of SMPN 48 Kerinci" (2020), n. 27 July.

${ }^{53}$ Hendarman and Dkk, Konsep Dan Pedoman Penguatan Pendidikan Karakter, 41.

${ }^{54}$ Candra, "Interview Teacher of SMPN 13 Kerinci," n. 16 July.

55 Idialisna, "Interview Teacher of SMPN 15 Kerinci," n. 28 July.

${ }^{56}$ Safarial, "Interview Principal of SMPN 48 Kerinci," n. 15 June. 
of the interviewees said, "the extra-curricular activities carried out are AlQur'an reading training, and then leadership exercises in the student council, for example, then camp events are also in scouting." 57 In another source, the teacher stated, "The form of extra-curricular activities in our school includes scouting, student council activities, yasinan (reading Surah Yasin together), sports and so on."58

c. The Implementation of PPK based on community activities

The implementation of PPK is based on community activities, carried out by strengthening the involvement of school committees, parents /guardians of students, community leaders, and other stakeholders in the planning and implementation of PPK. Community participation is conducted by empowering the potential of the environment and society as a learning resource such as social and community organizations, arts and cultural activists, alumni, the business world, and the industrial world. The Implementation of PPK based on community activities aims at synergizing PPK with a variety of dynamic programs.

Based on the results of interviews with community elements, it is known that the public is quite enthusiastic and welcomes the PPK movement in school. This condition is characterized by the active participation of parents/guardians of students, school committees, and community leaders planning and implementing formal and non-formal activities in schools. However, the participation of the community is still minimal and limited. This is in accordance with the results of interviews with parents and elements of the school committee that give a similar statement: "We are more involved only in the business of operational financing of the school. We are regularly invited to meetings with the committee in the early semester or the beginning of the year of learning. Regarding PPK implementation, parents and the community stated, "the school has never invited us to talk about the program specifically."

\section{Conclusion}

The implementation of the movement of Character Education Strengthening (PPK) in SMPN in Kerinci District has been running in accordance with existing guidelines. The implementation is in two stages, namely the pre-implementation stage and the implementation stage. Activities in the pre-implementation stage include the determination of

\footnotetext{
${ }^{57}$ Putra, "Interview Teacher of SMPN 48 Kerinci," n. 20 July.

58 Melta, "Interview Teacher of SMPN 48 Kerinci," n. 3 August.
} 
vision, school mission, determination of school branding, preparation of school programs that integrate PPK values, socialization of programs, and preparation of facilities and infrastructure and supporting equipment. While at the implementation stage, the implementation of PPK is based on class, school culture, and community. The implementation of PPK has brought a positive impact for strengthening the character of students with indicators of increased discipline. The respect and students' politeness towards teachers have begun to change. Next, the attitude of students' religion (religiosity) has begun to grow and develop. The students' environmental concern has also begun to increase. Additionally, the sense of awareness and responsibility of students has changed. There has been a change in mutual attitude and cooperation. Furthermore, the atmosphere of familiarity of fellow students has begun to improve, and the atmosphere of teaching and learning is felt more calm and comfortable.

However, the implementation of the PPK movement has not been implemented effectively and efficiently, so it has not brought maximum impact. The condition is caused because teachers have not yet understood the essence and urgency of the PKK movement comprehensively and intact and other factors such as inadequate learning facilities and resources and still lack of support and participation from the community and other stakeholders.

\section{Bibliography}

Creswell, John W. Qualitatif Inquiry and Designe Research Choosing among Five Approaches. London: Sage Publications, 2007.

Effendy, Muhadjir. "No TitleArahan Menteri Pendidikan Dan Kebudayaan Muhadjir Effendy Dalam Pelatihan Pengembangan Kapasitas Untuk Penguatan Pendidikan Karakter." 2016.

Gunawan, Heri. Pendidikan Karakter Konsep Dan Implementasi. Cet. Ke-1. Bandung: Alfabeta, 2012.

Hendarman, and Dkk. Konsep Dan Pedoman Penguatan Pendidikan Karakter. Cet. Ke-2. Jakarta: Kemendikbud, 2018.

Miles, and Huberman. Analisis Data Kualitatif, Buku Sumber Tentang MetodeMetode Baru. Jakarta: Universitas Indonesia Press, 2007.

Moleong, Lexy J. Metode Penelitian Kualitatif. Bandung: Remaja Rosdakarya, 2014. 
134 | AJIS : Academic Journal of Islamic Studies, vol. 6, no. 1, 2021

Permendikbud. Penguatan Pendidikan Karakter pada Satuan Pendidikan Formal, Pub. L. No. No. 20 Pasal 2 (2018).

Presiden, Peraturan. Penguatan Pendidikan Karakter, Pub. L. No. No. 87 Pasal 1 Ayat 1 (2017). 